\title{
Fiat justitia, ruat coelum: Is the International Court of Justice aware of this?
}

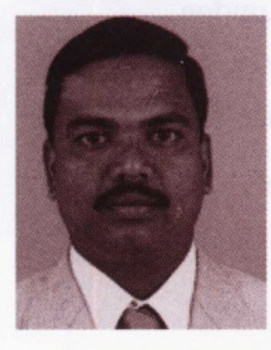

D Shanmuganathan

\author{
by D Shanmuganathan
}

The author takes a critical look at the ICJ's advisory opinion in a case involving defamation suits filed by Malaysian lawyers against a Special Rapporteur to the United Nations Commission on Human Rights in Malaysia

$\Lambda$ collision between the Malaysian Courts and the United Nations has been averted by the International Court of yustice (hereafter ICJ) through its Advisory Opinion, on the question of diplomatic immunity for Mr Dato Param Cumaraswamy (hereafter Mr Cumaraswamy), a Special Rapporteur to the United Nations Commission on Human Rights in Malaysia (see Difference Relating to Immunity from Legal Process of a Special Rapporteur of the Commission on Human Rights (1999) 38 International Legal Material 873). A controversial interview given by the Special Rapporteur alleged that some of the lawyers and litigants in Malaysia adopted the technique of 'judge choosing' for favourable judgments. This allegation sparked a row between certain firms and the Special Rapporteur, and this led to the filing of defamation suits against him. The Special Rapporteur claimed diplomatic immunity with the aid of a certificate issued by the United Nations Secretary General. The Malaysian courts declined to accept the stand taken by the Special Rapporteur and preceded with the suits (see Dato' Param Cumaraswamy v MBf Capital Bhd and another (1997) 3 Malayan Law Journal 824). The United Nations Secretary General requested the ICJ, through the Economic and Social Council (hereafter ECOSOC), for an Advisory Opinion on the disputed issue of diplomatic immunity. On 29 April 1999 the ICJ, by a 14:1 majority, declared that the Special Rapporteur was entitled to immunity following its earlier Opinion in the Dr Mazilu case (see Advisory Opinion on the Applicability of Article VI, section 22 of the Convention on the Privileges and Immunities of the United Nations (1990) 29 ILM 98).

The following discussion will show why the Malaysian courts refused to acknowledge the Special Rapporteur's claim to immunity and how the ICJ's Opinion rescued the United Nations from paying compensation to the Malaysian firms. Further, this discussion will establish the failure and misconception of the facts by the majority Opinion, which led to the miscarriage of justice akin to David losing to Goliath.

\section{DIPLOMATIC IMMUNITY AND THE DOMESTIC COURTS OF MALAYSIA}

\section{Mission and mandate}

Mr Cumaraswamy, a leading Malaysian advocate, was appointed by the United Nations Commission on Human Rights as the Special Rapporteur on the Independence of the Judiciary in Malaysia for a period of three years. The mandate entrusted to him was three fold:

(1) To inquire into any substantial allegations transmitted to him or her and report his or her conclusions thereon;

(2) To identify and record not only attacks on the independence of the judiciary, lawyers and court officials but also progress achieved in protecting and enhancing their independence, and make concrete recommendations including the provision of advisory services or technical assistance when they are requested by the State concerned;

(3) To study, for the purpose of making proposals, important and topical questions of principle with a view to protecting and enhancing the independence of the judiciary and lawyers (see (1994) 20 Commonwealth Law Bulletin 957).

\section{Controversial interview and the defamation litigation}

$\mathrm{Mr}$ Samuels for the International Commercial Litigation Journal interviewed Mr Cumaraswamy (Malaysian Justice on Trial) and during the interview, Mr Cumaraswamy alleged that the lawyers and litigants in Malaysia had adopted a practice of 'judge choosing' in order to obtain favourable judgments. He pointed out a particular case and said:

'This case looks like a very obvious, perhaps even glaring, example of judge choosing... the "judge choosing" allegations in the Ayer Molek affair, people first started to question the integrity of the judiciary after the US $\$ 4 \mathrm{~m}(\mathrm{RM} 10 \mathrm{~m})$ libel award Vincent Tan received on 22 October last year'.(Samuels, D, 'Malaysian 
Justice on Trial' (1995) International Commercial Litigation, p. 10)

The firms to which Mr Cumaraswamy referred in his interview issued legal notice stating that the International Commercial Litigation interview had gravely and seriously injured their trading reputation and brought them into public scandal, odium and contempt. Responding to the legal notice, Mr Cumaraswamy claimed that, being the UN Special Rapporteur, he was protected by diplomatic immunity. To that effect, the Centre for Human Rights of the UN Office at Geneva informed the firms' solicitors that the Special Rapporteur had immunity from legal process under Article VI, section 22 of the Convention on the Privileges and Immunities of the UN 1946 (hereafter the 1946 Convention).

'Section 22- Experts (other than officials coming within the scope of article V) performing missions for the United Nations shall be accorded such privileges and immunities as are necessary for the independent exercise of their functions during the period of their missions, including the time spent on journeys in connection with their missions. In particularly they shall be accorded: in respect of words spoken or written and acts done by them in the course of performance of their mission, immunity from legal process of every kind. This immunity from legal process shall continue to be accorded notwithstanding that the persons concerned are no longer employed as missions for the United Nations'.

Mr Cumaraswamy also claimed immunity by virtue of his mandate as well as Article 12 of the Diplomatic Privileges (UN \& ICJ) Order 1949:

'Except in so far as in any particular case any privilege or immunity waived the Secretary of the United Nations shall enjoy:

(b) immunity from legal process of every kind in respect of words spoken or written and all acts done by them in the exercise of these functions'.

The reply by Mr Cumaraswamy and the UN Human Rights Commission did not provide satisfaction to the firms, who eventually filed suits for defamation and claimed a sum of RM15m (RM6 = approximately $£ 1)$ for damages and exemplary costs. Mr Cumaraswamy filed an application to dismiss the suit in limine on the ground of diplomatic immunity provided to him by virtue of Article VI of the 1946 Convention.

\section{High Court and Court of Appeal's decisions}

The Judicial Commissioner (JC), who initially dealt with this case, discussed the Advisory Opinion of the ICJ in the Dr Mazilu case, on the applicability of Article VI, section 22 of the Convention on the Privileges and Immunities of the UN. However, the JC held that, on a point of public international law, the ICJ Advisory Opinion was not binding in the national courts and that the issue of absolute immunity could only be decided by trial. Hence, the JC dismissed Mr Cumaraswamy's application with costs (see (1997) 3 Malayan Law Journal 300).
Against the order of the JC, Mr Cumaraswamy appealed to the Court of Appeal, questioning the postponement of a decision in the immunity issue. The Court of Appeal identified the following issue in its discussion to answer the appeal by Mr Cumaraswamy.

\section{Whether the competence to make decision lies with the courts or with the UN}

The Court of Appeal discussed this issue at length, alleging that the UN Secretary General interfered with the function of the judiciary in the Member State. The Court of Appeal distinguished the wording of section 22 of Article VI of the Convention on Privileges and Immunities of the UN, Article 12(b) of the Diplomatic Privileges (UN \& ICJ) Order 1949 with the UN Secretary General's certificate to the Malaysian government stating that the Special Rapporteur had immunity from legal process. The UN Secretary General's certificate states:

\section{'To Whom It May Concern}

In connection with civil suit No S3023-68-1996 by Mbf Capital Bhd and Mbf Northern Securities Sdn Bhd against Dato' Param Cumaraswamy, the Secretary General of the United Nations hereby notifies the competent authorities of Malaysia that Dato' Param Cumaraswamy, national of Malaysia, is the Special Rapporteur on the Independence of Judges and Lawyers of the United Nations Commission on Human Rights. In this capacity, Dato' Param Cumaraswamy is entitled to the privileges and immunities accorded to experts performing missions for the United Nations under arts VI and VII of the Convention on the Privileges and Immunities of the United Nations to which Malaysia has been a party since 26 October 1957 without any reservation.

In accordance with s 22 of art VI of the Convention, "experts... performing missions for the United Nations shall be accorded such privileges and immunities as are necessary for the independent exercise of their functions...." Section 22 (b) of the Convention further provides that, "they shall be accorded, in respect of words spoken or written and acts done by them in the course of performance of their mission, immunity from legal process of every kind." As such, the Special Rapporteur on the Independence of Judges and Lawyers is immune from legal process of every kind in respect of words spoken or written and acts done by him in the course of performance of his mission.

The Secretary General determined that the words, which constitute the basis of the plaintiff's complaint, in this case were spoken by the Special Rapporteur in the course of his mission. [emphasis added] The Secretary General therefore maintains that Dato' Param Cumaraswamy is immune from legal process with respect thereto. Under s 34 of the Convention, the Government of Malaysia has a legal obligation to "be in a position under its own to give effect to the terms of this Convention." The Secretary General of the United Nations therefore requests the competent authorities to extend to Dato' Param Cumaraswamy the privileges and immunities, courtesies and facilities to which he is entitled under the Convention on the Privileges and Immunities of the United Nations'. (see (1997) 3 Malayan Law Journal 824 at p. 840-1) 
The Court of Appeal criticised the above certificate as mere ipse dixit, and declared that:

'...the Secretary General may by the stroke of his pen exclude the powers of the High Court to make factual determination upon which the defendant's immunity is postulated is, with respect, an invitation to journey from the sublime to the ridiculous, which we must with respect, decline to accept'. (see (1997) 3 Malayan Law Journal 824 at p. 843)

The Court of Appeal noted the deletion of the word performance in the UN Secretary General's certificate and decided that the certificate was neither in accordance with section 22 (b) of Article VI of the Convention $\left[{ }^{6}\right.$.... in respect of words spoken or written and acts done by them in the course of performance of their mission, immunity from legal process of every kind'] nor did it resemble the wordings of the 1949 Order '... in respect of words spoken or written and all acts done by them in the exercise of these functions'. The certificate provides a wider meaning than the 1946 Convention and the UN \& ICJ Order. The Court of Appeal rejected Mr Cumaraswamy's appeal on citing the mandate entrusted to him and held:

'The scope of the defendant's function is to inquire and report to the Commission on Human Rights upon matters that concern the independence of judges and lawyers. Nowhere by its terms does the mandate authorize interviews to members of the press'. (see (1997) 3 Malayan Law Journal 824 at p. 849)

The Court of Appeal directed Mr Cumaraswamy to stand trial before the Judicial Commissioner.

\section{ADVISORY OPINION OF THE INTERNATIONAL COURT OF JUSTICE}

The decision of the Malaysian national courts, discussed above, on the issue of diplomatic immunity for the Special Rapporteur eventually reached the ICJ through the UN Secretary General's request. The ICJ failed to address the request of the UN Secretary General or the pleadings of the Malaysian Government. However, by an evasive Advisory Opinion, the ICJ saved the United Nations from paying damages to the Malaysian plaintiffs, as can be seen in the following discussion.

\section{Pleadings}

The Secretary General initially requested the ICJ through the ECOSOC to determine his power to decide:

'1. Whether he has exclusive authority to determine that the words were spoken in the course of the performance of a mission?

2. On the basis of his determination, whether the Malaysian Government was bound by its legal obligation to inform its national courts, and if failing to do so, to assume the responsibility for costs, expenses and damages, if any?' (see (1999) 38 ILM 873 at p. 883)

The language employed in the Secretary General's certificate issued to the Malaysian Government varies from his request to the ICJ. Later the ECOSOC modified the UN Secretary General's request as:

'1. To determine the applicability of Article VI, section 22 of the Convention of Privileges and Immunities of the United Nations in the case of Dato' Param Cumaraswamy as Special Rapporteur of the Commission on Human Rights on the Independence of Judges and Lawyers

2. A request to stay all proceedings relating to this matter in Malaysian national courts through its Government'. (see (1999) 38 ILM 873 at p. 875)

This modification totally contradicts the initial request of the UN Secretary General. According to Judge Koroma (ICJ), although the ECOSOC was entitled to change or alter the request, it did so without any explanation being offered. The Malaysian Government in its written statement, citing section 22 of the Convention on the Privileges and Immunities of the UN, questioned the legal authority of the UN Secretary General to determine that the words were spoken in the course of the performance of a mission. It was further contended by the Malaysian Government that the modification of the request by ECOSOC was not valid on the grounds that the ECOSOC was only an instrument to convey the request of the UN Secretary General to the Court and therefore it could not alter the request. In spite of this, on citing the Dr Mazilu case the ICJ, in a majority Opinion of $14: 1$, held that the Special Rapporteur was entitled to immunity.

\section{David lost to Goliath}

The ICJ failed to consider the UN Secretary General's certificate and whether he had issued the certificate in accordance with his powers and the law. Paragraph 52 of the ICJ's Opinion said:

'In the present case, the Secretary-General, or the Legal Counsel for the UN on his behalf, has on numerous occasions informed the Government of Malaysia of his finding that $\mathrm{Mr}$ Cumaraswamy had spoken the words quoted in the article in International Commercial Litigation in his capacity as Special Rapporteur of the Commission and that he consequently was entitled to immunity from "every kind' of legal process". (see (1999) 38 ILM 873 at p. 891-2)

This was despite the fact that the Court of Appeal in Malaysia had found that the UN Secretary General's certificate provides a wider meaning than the text of section 22 (b) of Article VI of the 1949 Convention and Article 12 (b) of UN \& ICJ Order 1949. Moreover, the ICJ accepted the certificate of the UN Secretary General, which is not in accordance with law. The ICJ failed to note that the certificate issued by the UN Secretary General to the Malaysian Government was in contrast with his request to the ICJ through the ECOSOC. The UN Secretary General stated in his certificate that the words were spoken by the Special Rapporteur in the course of his mission. However, the UN Secretary General requested the ICJ 
through the ECOSOC, to determine that the words were spoken in the course of the performance of a mission. The judges of the majority Opinion failed to note the clandestine approach of the UN Secretary General, who has not come to the Court of Justice with clean hands. Examining the ICJ's approach to this issue, it is evident that it did not function as a judicial organ, but merely as an executive of the UN to save the payment of compensation to the Malaysian firms/plaintiffs.

The Special Rapporteur's interview to International Commercial Litigation, according to the ICJ, was well within his mandate and it underlined two distinct factors to vindicate its stand, namely;

'1. In the pleadings and arguments, the UN contended that it is 'usual practice' for the Special Rapporteur to have contact with the media.

2. In a letter dated 2-10-98, the High Commissioner of the Human Rights Commissioner stated:

“...it is more common than not for Special Rapporteurs to speak to the press about matters pertaining to their investigations, thereby keeping the general public informed of their work.". (see (1999) 38 ILM 873 at p. 892)

It is suggested that these factors are neither in accordance with law nor authorised in the mandate entrusted to the Special Rapporteur. Even worse is the ICJ's reliance on a letter written by the High Commissioner of the Human Rights Commission, who was neither a party to the Opinion, nor has the power to declare that the Special Rapporteur was immune from any legal proceedings. Nevertheless, the High Commissioner declared that it is common for Special Rapporteurs to have contact with the media. Even assuming that Special Rapporteurs do sometimes contact the media to raise public awareness regarding their mandates, $\mathrm{Mr}$ Cumarasawmy's interview not only mentioned his work, but also alleged named individuals had committed illegal acts and according to the Malaysian Court of Appeal this was something which had to be beyond his mandate.

Moreover, the ICJ assumed that, although litigation was pending against Mr Cumaraswamy, the fact that he was given an extension for another three years, in 1997, clearly showed that he had acted within his mandate, otherwise his term would not have been extended. This assumption could also be interpreted as though the UN, by extending Mr Cumaraswamy's term, were protecting him within the ambit of immunity to save the payment of compensation to the Malaysians firms/plaintiffs.

Moreover, the ICJ directed that national courts should give the UN Secretary General's certificate the greatest weight and that it could only be set aside for the most compelling of reasons. If this is the position should it be treated as genuine, even if the certificate was misleading the court? One would come to a conclusion that the UN Secretary General had been given a free hand by the ICJ to issue certificates as he/she likes which should be treated as bonafide by the domestic courts.

Even though the ICJ declared that Mr Cumaraswamy was immune from any legal proceedings, the best compelling reasons known to the ICJ was to make the following advice to the UN agents:

$\therefore$...all agents of the United Nations, in whatever official capacity they act, must take care not to exceed the scope of their functions, and should so comport themselves to avoid claims against the United Nations'. (see (1999) 38 ILM 873 at p. 894]

The ICJ failed to note that the facts and circumstances in Dr Mazilu's case, in which he was prevented from submitting reports and attending conferences by the Romanian Government; on the other hand the Malaysian Government had done nothing to Mr Cumaraswamy. Therefore it could not be relied on as a precedent.

Due to the above untenable, ill-equipped reasoning and the biased umpiring of the ICJ, David lost to Goliath. It is a shame that Goliath's foul game was vindicated by some of the Member States; the UK, the US and Italy to name but a few. These Member States voluntarily abetted in a 'broad day light judicial murder'.

\section{CONCLUSION}

Although both parties agreed on the ICJ's jurisdiction to give an Advisory Opinion in relation to the dispute, the Court nevertheless devoted the major part of its Opinion to the jurisdiction issue. Moreover, the ICJ's advice to UN agents, to avoid claims in future against the UN, exposes the weakness of its Opinion. Instead of advising the UN agents, the ICJ should have directed the UN Secretary General to issue certificates in accordance with law.

It is suggested that in reaching this Opinion, the ICJ departed from being an independent body of the UN and acted as a mouthpiece of the UN. Though, as the ICJ's Opinion is final, no justice has been rendered, and what remains is miscarriage of justice. Let us remind the judges of the ICJ with Lord Atkin's statement:

'Finality is a good thing, but justice is a better'. (see (1933) 50 Times Law Reports 1 at p. 2)

Judge Koroma said that he, due to his legal conscience, disagreed with the majority, so could we therefore presume that the judges who were party to the majority have no conviction of their legal conscience? If the answer is in the affirmative, David will always lose to Goliath and the celebrated legal maxim fiat justitia ruat coelum will be a dead letter in the ICJ.

D Shanmuganathan MSc, BL, LLM (Wales)

PhD Student, Department of Law, University of Wales, Aberystwyth 